A. E. Kuznetsov ab

ORCID: 0000-0003-4541-1498

⿶recubanssub@googlemail.com

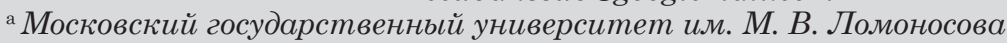

(Россия, Москва)

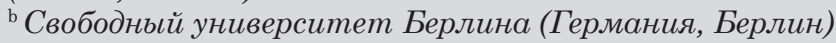

\title{
TRANSFORMATIONS OF THE WORLD SPACE: From Pliny's Natural History to the Collectanea Rerum MEMORABILIUM of C. Julius Solinus AND THE POEM De Mirabilibus of Theodericus
}

\begin{abstract}
Аннотация. В статье рассматриваются два последовательно сделанных сокращения «Естественной истории» Плиния Старшего: «Собрание достопамятных вещей» Гая Юлия Солина и средневековое сокращение Солина, сделанное в стихах неким Теодериком. Основное внимание уделяется той части «Collectanea», в которой дается географический упорядоченный обзор Экумены, соответствуюший книгам 3-6 Плиния. Геоградическая часть представляет особый интерес для понимания поэмы Теодерика. Анализ структуры текста позволяет выявить глубинные различия между исследуемыми авторами. Эти различия могут быть интерпретированы как изменения глобальных представлений о мировом географическом пространстве. Для Солина большой мировой континуум был основой для упорядочения почерпнутого у Плиния энщиклопедического материала, который у Солина структурирован наподобие современной базы данных. Эта структура названа в статье ветвящимся каталогом. В отличие от Солина, Теодерик полностью утратил идею Мирового континуума. Он не упоминает большую часть географических названий, и названия больших областей за редкими исключениями опущены. При этом он демонстрирует непоследовательную тенденщию сводить сведения, взятые у Солина, $к$ тематическим блокам. В целом Теодерик имел смутное представление о том, как устроен мир в географическом пространстве, поэтому он не мог распознать явные ошибки в в своем экземпляре сочинения Солина, которые могли затронуть связность географического континуума. Пренебрежение географическим пространством можно объяснить тем, что поэма, вероятно, создавалась как многоуровневая аллегория, в которой географическая локализация не имела существенного значения.
\end{abstract}

Ключевые слова: античная география, средневековая географрия, диахрония пространств, пространство в литературе, критика текста, бестиарии, монстры в литературе, средневековая поэзия, Плиний Старший, Гай Юлий Солин 
Для иитирования: Kuznetsov A. E. Transformations of the world space: From Pliny's Natural History to the Collectanea Rerum Memorabilium of C. Julius Solinus and the poem De Mirabilibus of Theodericus // Шаги/Steps. Т. 6. № 1. 2020. C. 113-145. DOI: 10.22394/2412-9410-2020-6-1-113-145.

Статья поступила в редакиию 8 октября 2019 г.

Принято к печати 3 декабря 2019 г.

Shagi / Steps. Vol. 6. No. 1. 2020

Articles
A. E. Kuznetsov ab
ORCID: 0000-0003-4541-1498
recubanssub@googlemail.com
${ }^{a}$ Lomonosov Moscow State University (Russia, Moscow)
${ }^{\mathrm{b}}$ Free University of Berlin (Germany, Berlin)

\title{
TRANSFORMATIONS OF THE WORLD SPACE: From Pliny's Natural History to the Collectanea Rerum MEMORABILIUM OF C. Julius Solinus AND THE POEM De Mirabilibus of Theodericus
}

\begin{abstract}
Two successive abridgements of Pliny's Natural History are discussed in the paper: the Collectanea rerum memorabilium by C. Julius Solinus and a medieval abridgement of Solinus, made in verse by a certain Theodericus. The main attention is paid to the biggest part of the Collectanea which gives a geographical account of the Universe corresponding to Pliny's Books 3-6. The geographical part of the Collectanea is of particular interest for understanding the poem of Theodericus. An analysis of the text structures reveals deep differences between the studied authors. These differences can be interpreted as changes in global concepts of the World geographic space. For Solinus, the large World space was a basis for arranging the encyclopedic material drawn from Pliny, and he created a universal continuum of information that looks somewhat similar to the modern data-base structure: I call it the ramifying catalogue. In contrast to Solinus, Theodericus completely lost the idea of a World continuum. Theodericus does not mention the greater part of the geographical names, and names of large regions are all omitted, save for a few exceptions. Theodericus, however, shows a tendency to reduce the matter of the Collectanea to thematic units. Since Theodericus had but a very vague idea of how the World was arranged in geographical space, he could not recognize evident scribal errors of his copy of Solinus' work which affected the coherence of the geographical continuum. A neglect of the geographical space can be explained by the fact that the poem was probably intended to be read as a multilevel allegory where geographical localization would be of little importance.
\end{abstract}


Keywords: ancient geography, medieval geography, diachrony of space, space in literature, textual criticism, bestiary, monsters in literature, medieval poetry, Pliny the Elder, C. Julius Solinus

To cite this article: Kuznetsov, A. E. (2020). Transformations of the world space: From Pliny's Natural History to the Collectanea Rerum Memorabilium of C. Julius Solinus and the poem De Mirabilibus of Theodericus. Shagi/Steps, 6(1), 113-145. DOI: 10.22394/2412-9410-2020-6-1-113-145.

Received October 8, 2019

Accepted December 3, 2019

\section{Theodericus and his poem}

A poet who called himself Theodericus composed a versified paraphrase of the Collectanea rerum memorabilium of C. Iulius Solinus ${ }^{1}$. The poem has no title, and I shall call it De mirabilibus ${ }^{2}$. It is composed in 1186 leonine hexameters which are irreproachable from the point of view of quantitative prosody. The best, and eventually the only reliable manuscript of De mirabilibus is the Codex Bruxellensis Regius BR 10615-7293, which was written in Trier in the third quarter of the $12^{\text {th }}$ century, but it is impossible to determine the distance in space and time that lay between this earliest copy and the original autograph. The manuscripts of De mirabilibus contain two other leonine poems that may have been composed

${ }^{1}$ Solinus' work exists in two versions. The earlier one is preserved in manuscripts defined by Mommsen [1895] as the first class. The earlier version is accompanied by a dedicatory letter where no title of the work is mentioned. The later version is found in manuscripts of the third class which contain a new dedicatory letter with the statement that the old title Collectanea rerum memorabilium should be suppressed, and the corrected work is to be called Polyhistor (p. 217, 17-21 Mommsen). The later version contains a few additions. Manuscripts of the second class have the same dedicatory letter as the first class, but they contain additions, often in common with the third class. Mommsen was convinced that the later version had been a work of an unknown grammarian [Ibid.: lxxxviii]. Against Mommsen's authority Peter L. Schmidt has argued that the second version can be considered a genuine work by Solinus [Schmidt 1995]. The problem of two versions is too large and complex to discuss here; suffice it to say that Theodericus used a manuscript of the second class ( $\S 10$ below). It is important, however, to keep in mind that the text published by Mommsen was arranged as an edition of the 'non-interpolated' first version, and a critical text of the second version to date has never been edited. For Mommsen did not distinguish between genuine additions of the corrected version and interpolations that appear in different mss. Selected additions of the third and second classes were printed by Mommsen separately, without the apparatus, under the title Codicum classium secundae et tertiae additamenta potiora [Mommsen 1895: 217-221]. The Collectanea were first printed in 1474 (GW M42824) with the preface of the first version. See [Schmidt 1995; Brodersen 2011; 2014] for a reliable bibliography on Solinus, and [Dover 2013] for the Renaissance reception.

${ }^{2}$ The poem has never been fully edited, and this paper is based on - still unpublished critical edition prepared by Prof. Dr. Rainer Jakobi (Martin-Luther-Universität, Halle-Wittenberg) and the author of this paper.

${ }^{3}$ Manuscripts of the poem were listed by Mommsen in his edition of Solinus [Mommsen 1895: liii]. For the Codex Bruxellensis see [Kaffarnik 2011; Verweij 2015]. Besides De mirabilibus, the manuscript contains other large poetic compositions datable to the $11^{\text {th }}$ - early $12^{\text {th }}$ cent.: a poem on the First Crusade by Gelo Parisiensis and the most full copy of the Carmen de Hastingae Proelio. The entire manuscript was first described by Frédéric baron de Reiffenberg [1841]; he, and later Manitius, published some excerpts from the poem [Ibid.: 258-262; Manitius 1913: 160-162]. 
by Theodericus: a description of the Tower of the Winds in Athens (from Vitruvius 1.6), and an Elegy on the death of Theodericus' dog (incipit flete canes $^{4}$ ). We cannot be sure about the authorship of these two works, but the author of the Elegy, if he was not Theodericus himself, must have known him personally. In the Elegy, a line from the Liber decem capitulorum of Marbode of Rennes (written after 1096) is quoted almost literally:

$\begin{aligned} \text { Flete canes, } 57 & \begin{array}{l}\text { Morte sua vitam seruaverat ille poete } \\ \text { (his death saved the life of the poet) }\end{array} \\ \text { Marbodus, Decem capitula, } & \begin{array}{l}\text { Morte sua vitam regis servasse mariti } \\ \text { (her death saved the life of her spouse king) }\end{array}\end{aligned}$

This suggests that the floruit of Theodericus is likely to be dated back to the late $11^{\text {th }}$ - early $12^{\text {th }}$ century.

A part of De mirabilibus (vv. 974-1093) is copied without the name of the author in a Vienna manuscript that contains a collection of geographical works (Österreichische Nationalbibliothek, Cod. 507, 13 ${ }^{\text {th }}$ cent.). The Vienna excerpt is entitled De monstris Indię. Christian Hünemörder, who first published the Vienna fragment, failed to identify it with the selections from De mirabilibus, by then published [Hünemörder 1976: 271]. Hünemörder, however, has argued from textual evidence that the poet of De monstris Indie had drawn on the treatise Imago Mundi by Honorius Augustodunensis. The Vienna extract has been identified as Theodericus' work by Rainer Jakobi [2002]. Since the first version of Imago Mundi was finished in 1110 [Flint 1982: 40], and, in turn, De mirabilibus was abridged by an unknown poet called Ovidius some time before $1140^{5}$, Jakobi has concluded that the De mirabilibus was composed ca. 1120 [2002: 250]. It is a plausible assumption that a poetic work like the De mirabilibus is secondary to a prose composition on the same subject, if both are textually related to one another. But the true relation between the texts in question is difficult to establish, and inverse borrowing from Theodericus to Honorius cannot be excluded, in which case the date of Theodericus would be moved back the late $11^{\text {th }}$ century. Further consideration of this problem would require a detailed comparison of the two works that exceeds the scope of the present paper.

The poem itself contains almost nothing about Theodericus. We learn that he had a friend named Stephanus who encouraged him to finish De mirabilibus, and the Elegy states that the above mentioned dog was called Pitulus. These facts do not allow to draw any conclusions. The name Theodericus was very popular, and suggested identifications with known historical persons can only be regarded as highly uncertain ${ }^{6}$.

It is not easy to establish the genre of De mirabilibus more precisely than Lehrgedicht. In this paper I shall argue that Theodericus did not arrange his poem according to any principle of composition, as it was done in Imago Mundi, or in a Carolingian treatise, Liber monstrorum de diversis generibus [Haupt 1876], so it is not likely that Theodericus intended to compose an encyclopedic work.

\footnotetext{
${ }^{4}$ Text: [Manitius 1914: 161-163; Ziolkowski, Putnam 2008: 481-485].

5 'Ovidius' was described and edited by [James 1913]. Jakoby has convincingly demonstrated that 'Ovidius' depends on Theodericus [Jakobi 2002: 249].

${ }^{6}$ The most widely accepted attribution is Thierry, the Abbot of St. Trond [Manitius 1913: 160], but Thierry died in 1107. The relation between De mirabilibus and Imago mundi is thus of crucial importance for identification of revealing the personality of Theodericus.
} 


\section{Solinus: The structure of the universe, and the place of Rome in the World}

Before we consider the abridgement, we need to consider its source, Solinus, whose work was itself an abridgement of Natural History, and we should always have Pliny in mind when studying his descendants, Solinus and Theodericus.

The Collectanea are divided into three parts. In the first one, Solinus narrates different stories referring to the foundation of Rome, and recounts at length the history of the Roman calendar until the calendar reform carried out by Augustus (Sol. 1.34-47 p. 9,9-11,22 Mommsen). Here Solinus drew largely on non-Plinian sources. The first part ends with a short discussion on Augustus (calamitiosior an beatior fuerit, Sol. 1.48-49 11,23-12,13 M $\rightarrow$ Plin. 7.145-150). The second part, in which the human being is dealt with, is based largely on the Book 7 of Natural History. This section contains, among other themes, a vast list of examples of Roman military fortitude, and catalogues of persons who became famous due to their moral virtues or eloquence (Sol. 1.102-127 26,6-31,5 M). Those people are in large part Roman too.

The third part is the biggest one. It gives a geographical account of the Universe corresponding to Pliny's Books 3-6. In this paper, I shall deal mainly with the geographical part of the Collectanea, because it is of particular interest for understanding Theodericus.

A relatively short treatise by Silinus and an even shorter poem by Theodericus still inherited from Pliny a feature of fundamental importance: the abridgments sought to offer a picture of the Universe. Pliny's Universe was essentially the Roman Universe, and this leads us to the question of how Rome is represented in the Historia Naturalis. Pliny gives a short description of Rome in the section on Italy (Plin. 3.66-67), but Rome of the Historia Naturalis was more than an item of a geographical catalogue, she was even more than the political center of a great empire. Rome was the unifying power of the World which gained dominance over an immense mass of individual phenomena, and created from that mass an actual, visible and palpable, universal nature ${ }^{7}$. Rare and marvelous things had a particular importance for this cosmological system, because the Roman state absorbed natural and artificial mirabilia from every part of the World, and the City of Rome became a large depository of those signs of power ${ }^{8}$. Pliny usually finds it necessary to tell when an exotic creature became first known and seen in Rome, adding the names of magistrates in charge of the show, and this makes the Historia Naturalis similar to an inventory of an everlasting triumphal procession, triumphus ex mundo, as one may call it. Eventually, historical triumphs are frequently mentioned by Pliny throughout his Encyclopedia ${ }^{9}$, and they often give an occasion to introduce various notable facts and items, e. g., L. Caecilius Metellus 'led many elephants' in his

${ }^{7}$ Before Pliny, Ovid declared that Rome became equated with the World, Fasti 1, 85: Iuppiter arce sua totum cum spectet in orbem, | nil nisi Romanum quod tueatur habet (When from his citadel Jupiter looks abroad on the whole globe, naught but the Roman empire meets his eye) (trans. by Frazer); see [Woodart 2006: 254-249] for the deep religious background of this idea.

${ }^{8}$ The mirabilia are recognized as an important part of the 'imperialistic' ideology of the Natural history [Naas 2011]. This aspect of the Roman attitude towards mirabilia recently has been studied, largely on the basis of the Natural History, in [Rutledge 2012].

${ }^{9}$ See [Murphy 2004: 154-160] on the importance of triumphs for Pliny. 
triumph in 250 BCE (Plin. 7.139). or the inhabitants of the land of Garamantes are numerated in an inventory of people and cities whose 'names and pictures' (nomina ac simulacra) were shown in a triumph of L. Cornelius Balbus in 19 BCE (Plin. 5.37). Solinus preserves some of those statements ${ }^{10}$.

The Roman element is not only present in the Collectanea, but is even expanded in some points. Nonetheless, it is impossible to state that Solinus inherited from Pliny the idea of Rome as the center of power which dominated over the Universe. The first part of the Collectanea does include a vast discourse on the Roman past compiled largely from non-Plinian sources, but non-Plinian interpolations do not necessarily attest a particular interest in Rome, since they are found in other parts of the Collectanea, where Solinus speaks about the origins and history of other lands and nations. It will be enough to mention the excurses about Thracia (Sol. 8.3-7 61,19-62,11 M), Macedonia (Sol. 9.4-21 63,12-66,20 M), Carthage (Sol. 27.912 117,7-17 M), and the fabulous empire of Cilicia (Sol. 38.1-6 161,3-162,9 M), which are likely to reflect the idea of succession of world-empires ${ }^{11}$. None of these interpolations are written from the point of view of Roman dominance, and Solinus might be similar in this regard to Pompeius Trogus ${ }^{12}$.

Solinus begins the geographical part with a long antiquarian discourse on the origins of Italian cities (2.2-18 31,9-36,8 M). He mentions Saturnia and Ianiculum (p. 32,1-2 M), but he does not mention Rome. It is reasonable to suggest that Solinus did not want to repeat what he had said about Rome in the initial chapters. The paradox is that Rome totally falls out from the geographical account of Italy, and, throughout the whole geographical part of the Collectanea, she is merely mentioned occasionally. It is worth observing that Carthage is treated in a similar way: Solinus says in the historical excursus, referred to above, that restored Carthage became 'the next after Rome splendour of the World' (alterum post urbem Romam terrarum decus, $117,7 \mathrm{M}$ ), nonetheless, the great city is omitted from the description of Africa, and, in the whole geographical part, no more than two accidental mentions are found: one emerges in a narration about the tomb of Hannibal in Libyssa (172,7 M), another in a story concerning the monstrous creatures (probably gorillas) captured by Hanno (211,5 M) [McDermott 1938: 51-55]. The mentions of Rome are more frequent $^{13}$, but they are equally accidental.

The presence of Rome in the world described by Solinus is significantly reduced compared to Natural History. On the other hand, stories about Rome are densely concentrated in the initial chapters of the Collectanea, wholly or mainly devoted to

${ }^{10}$ Sol. 27.22 120,15 M: Scaevola and leones; 30.20 133,17 M: Caesar and camelopardis; 30.21 134,3 M: Pompeius and rhinoceros; 32.31 145,6-7 M: Scaurus and hippopotami and crocodili; 34.1 153,13 M: Scaurus and bones of a sea-monster ( $\$ 7$ below); 52.52 193,3 M: Pompeius and the hebenus wood; 53.30 201,7 M: large pearls were introduced in the time of Sulla. Pliny, however, does not state explicitly that Numidici ursi were first shown in a great spectacle arranged by L. Domitius Ahenobarbus on 17 Sept. 61 BCE: Sol. 26.10 115,13 M $\rightarrow$ Plin. 8.131.

${ }^{11}$ Sol. 8.3-7 61,19-62,11 M; Sol. 9.4-21 63,12-66,20 M; Sol. 27.9-12 117,7-17 M. From the large literature on the succession of world-empires [Ramosino 2005] is of particular importance in the Plinian context.

${ }^{12}$ Solinus gives only one direct reference to Pompeius Trogus, and it is borrowed from Pliny: Sol. $1.5112,19 \mathrm{M} \rightarrow$ Plin. 7.33. [Seel 1982] remains the most lucid discussion of the universalism of Pompeius Trogus.

${ }^{13}$ According to the index of Mommsen's edition, there are about 20 occurrences of Roma, Romanus and Romani in the geographical part of the Collectanea. 
Roman history. This may suggest that the idea of Rome as the Universe was still shared by Solinus, but it was being moved toward a purely historical level, and Rome was associated with the past, rather than with the actually dominating cosmic power.

This approach to Rome is announced in the first version of the Preface: Solinus calls Rome 'the head of the World' (caput orbis, Praef., 5 2,18 M), and claims that with Rome he will begin his compendium. Yet, states Solinus, 'the most learned writers' left nothing untouched that could be spoken about as a new matter. Solinus does not want to repeat what was said in many old books, but he equally refuses to drop Rome altogether. The solution will be to write about the origins of Rome as reliably as possible (Praef., 7). Solinus carried out this program in good faith, and the chapters devoted to the early history of Rome appear to be the most original and non-Plinian part of the Collectanea.

A similar recusatio is used to introduce the description of Italy in the geographical part, and this section is filled mainly with antiquarian excurses mentioned above, but, as far as real information is concerned (2.19-50), Italy appears to be one of the most strictly compressed chapters of the Collectanea.

\section{Solinus: A disposition of the World}

The geographical part of the Collectanea is relatively large, but it covers only four books of Natural History. Solinus ${ }^{14}$, however, did not ignore the immense treasures of learning collected by Pliny in other books. He transformed Pliny's great encyclopedia into a short world-wide itinerary, and arranged geographically all the diversity of natural and human phenomena gathered from Pliny.

Solinus divided the world into large regions which are further described in the form of catalogues of smaller areas and geographical or chorographical objects, such as rivers and mountains. Each region is represented as an imaginary route through local areas, and, except for few breaks, all content of geographical chapters forms a continuous movement from Italy to the ultimate Eastern shores of Oecumene, and back through India to the Atlantic shore, where Canaria islands are the last point of Solinus' geographical discourse (see Appendix II to this paper) ${ }^{15}$.

Though the greater part of the World described in the Collectanea could never be visited by the Romans or the Greeks, Solinus steadily used expressions of route and travel to describe transgressions from one region or area to another, e. g. 46.4 177,16 M: hos terrarum ductus excepit Media 'these movement of countries is picked up by Media'. In these points, Solinus sometimes speaks metaphorically about the travel of his 'pen' ${ }^{16}$, e. g.: 3.1 44,13 M; flectendus hinc stilus est: terrarum vocant aliae... (here the pen must change the way, for other lands call us); 33.44

${ }^{14}$ I presume that Solinus relied directly on the Natural History, and that he was entirely responsible for the composition and content of the Collectanea; see [Brodersen 2011: 71] on Mommsen's theory of intermediate sources.

${ }^{15}$ Klauss Geus has recently demonstrated that a geographical arrangement is employed in the Paradoxographus Vaticanus as a 'secondary principle' subordinated to the thematic disposition [Geus 2016].

${ }^{16}$ Solinus could borrow the metaphor of journey from Pliny [Pavlock 2014], but for the Romans the linear route-pattern (called 'hodological' by Pietri Janni [1984]) probably was the most common way of representing geographical space. See the survey of this problem in [Talbert 2008]. 
147,13 M: nunc ab Aegypto provehamus stilum (now we are to carry the pen forward from Egypt); 56.4 206,3 M: tempus ad Oceani oras reverti, represso in Aethiopiam stilo (now it is time to return [from Babylonia] to the shores of the Ocean, after I shall hold my pen back to Ethiopia).

Solinus followed Natural History in distributing lands and regions throughout his catalogue with the exception of a few important shifts ${ }^{17}$. Still, the content of the geographical sections of the Collectanea differs significantly from Natural History.

Solinus used names of places as cells in which non-geographical items, such as animals, plants, stones, and exotic tribes, were located. Subordinated items can serve as host-entries at a lower level.

It is important to notice that connections established by Solinus between low level non-geographical units and their geographical host-entries are often arbitrary: hosts are not necessarily associated with subordinated items either in the natural order, or in Natural History. When Solinus seeks to create a general account of a creature which is not tied to a narrow geographical area (such as dolphins or bears, discussed below), he still gives a geographical localization.

Here I shall consider some examples that will further be helpful in understanding Theodericus.

Solinus says that the Propontis is particularly rich in dolphins, and this statement hosts a large collection of facts and stories about dolphins borrowed from Pliny (Sol. 12.3-12 78,3-80,6 M $\rightarrow$ Plin. 9.20-9.32). None of those items are located in the Propontis by Pliny, who in his section on dolphins does not mention the Propontis or Hellespont at all.

Similarly, Solinus anchored a survey of elephants (Sol. 25.2-15 111,3$113,15 \mathrm{M})$ to the description of Tingitana in Mauretania. Pliny does state (5.18) that the province of Tingitana produces elephants, but the section on elephants belongs to another book of Natural History (Plin. 8.1-44).

In the chapter on bears, Pliny remembered the famous show of Numidian bears produced by Domitius Ahenobarbus (n. 9 above). This geographical reference allowed Solinus to put an entire Plinian chapter on bears under the hostentry Numidia (Sol. 26.3-10 114,11-115,16 M $\rightarrow$ Plin. 8.126-131), though the information about bears provided by Pliny had nothing to do with that land (Pliny mentioned the bear when discussing hibernating animals). Moreover, Pliny doubted whether the Numidian bear existed altogether, 'because it is well known that there are no bears in Africa'. This phrase is, of course, omitted by Solinus, who went even further in manipulating his source text, so that he began the section on bears with a bold statement: Numidici ursi ceteris praestant rabie dumtaxat et villis profundioribus (Numidian bears surpass the others in ferocity, and, at least, in thicker fur $)^{18}$.

While Pliny often puts information related to some item into different thematic parts of Natural History, Solinus accumulates it under one and the same host-entry. He thus interpolates into the section on bears an observation about how those beasts treated themselves for mandragora poisoning (Sol. 26.8 115,8-10M $\rightarrow$ Plin. 8.101).

${ }^{17}$ Brodersen has argued that the arrangement of geographical matter in the Collectanea changed from the linear, largely litoral, pattern typical for Pliny and Pomponius Mella to a description of areas [Brodersen 2011: 72-86].

${ }^{18}$ The phrase is wrongly marked as borrowed from Plin. 8.131 in Mommsen's edition. 
A more complicated instance of contamination involves precious stones. In the book on mineralogy, Pliny created a large alphabetical list of stones which begins with the achates. He further mentioned different names and local varieties of the achates (37.139-142).

Solinus inserted this section into a description of Sicily, because the river Achates is situated there. The whole list of varieties of achates stones was transferred to that head-entry, though it contained the names of Crete, India and Cyprus, all of which were preserved by Solinus (Sol. 5.25-27). Solinus also added the description of a famous ring made of achates: he took this from another part of Book 37 of Natural History (Plin. 37.5).

Solinus returns to the theme of precious stones in the section on Mesopotamia (Sol. 37.7 sqq.), where a catalogue of gems is divided between four geographical entries which follow the movement from the upper reaches of Euphrates to the Persian Gulf: Euphrates, Chaldaei, Parthi, Persis. Stones mentioned here are in large part hosted by the entry Persis. This disorderly collection of minerals is gathered from different catalogues which Pliny included in Book 37, but the four hosting geographical entries are gathered directly from the alphabetical list of stones mentioned above. In the alphabetical list, Solinus found stones whose places of origin were occasionally referred to by Pliny:

mitrax (mithridax, Solinus) - Persis (Plin. 37.173) sagada - Chaldaei

(Plin. 37.181); zamilampis - Euphrates (Plin. 37.189).

The location of myrrhitis in Parthia (myrrhites, Plin. 37.174) is transferred from another place in Natural History, where myrrhina is mentioned, Plin. 37.21:

oriens myrrhina mittit. inveniuntur ibi pluribus locis ... nec insignibus, maxime Parthici regni (the Orient produces myrrhina, where it is found in numerous places..., especially in the Empire of the Persians).

Here, Solinus failed to recognize that myrrhina (fluorspar, fluorite, blue John [Healy 1999: 228-235]), and myrrhites (a kind of bitumen) reported by Pliny were different minerals.

Pliny treated a geographical localization as non-obligatory information added to a few items of the catalogue of stones:

$$
\text { List of stones } \rightarrow \text { sagada } \rightarrow \text { Chaldaei }
$$

This subordination was inverted by Solinus:

$$
\text { List of areas } \rightarrow \text { Chaldaei } \rightarrow \text { sagada }
$$

Solinus follows the same approach in non-geographical sections as well. Pliny provides a list of enormously strong men (Plin. 7.81-83), among whom the famous Olympic victor Milo of Croton is mentioned. Solinus abridged this section (Sol. 1.75-77), but he found it necessary to attach the stone alectoria to the note on Milo, because Milo had used this stone to strengthen his body. As in the case of achates, Solinus inverted the order of items. For he found the alectoria in the same alphabetical list of stones (Plin. 37.144) where Pliny mentions Milo as an item of additional remarkable information: 
Pliny: stones $\rightarrow$ alectoria $\rightarrow$ Milo

Solinus: strong men $\rightarrow$ Milo $\rightarrow$ alectoria

The same approach is followed with regard to non-Plinian sources. From Book 4 of Natural History Solinus received the statement that the Borysthenes originated in the Land of the Neuri (Sol. 15.1 82,5 M $\rightarrow$ Plin. 4.88). Mention of the Neuri hosts a series of excerpts about peoples of Scythia from Pomponius Mela $(2.1,6-14)$, and other interpolations on the same matter collected from Pliny. This block of interpolations ends with a description of the Albani gathered from two different books of Natural History (Sol. 15.5 83,3 M $\rightarrow$ Plin. 6.38; 7.12). From here Solinus moves to that point of Book 8 where Albanian dogs are described (Sol. 15.6 83,7 M $\rightarrow$ Plin. 8.149). Further on, the entry about Albanian dogs hosts a collection of items about dogs taken from Book 8, but in Natural History they all precede the Albanian dogs (Plin. 8.142-148). Although the composition of this section is very complicated, it is clear that the Plinian text served as a substratum for all those interpolations.

Similarly, one of the great routes of the Collectanea begins with an overview of the Black Sea, proceeds to the Caspian region, and ends with the description of tigers and panthers that dwell in Hyrcania (Sol. 17.4-17.11 90,8 M-91,19 M). The last section is taken from Plin. 8.43-101. Here, Solinus inserts the second description of the Pontus and the Caspian region, which is borrowed from Books 4 and 6, and leads as far as the eastern borders of Germania. At the end of this section, however, Solinus returns to Book 8, almost at the same point where he has left it in Hyrcania, and describes the animals of Scythia (19.9-18 94,3 M-95,14 M $\rightarrow$ Plin. 8.101-120).

\section{Solinus: A ramifying catalogue and patterns of memory}

Solinus had to do meticulous and arduous work in order to rearrange the mass of names and facts he gathered from Natural History. As a result, he created a universal continuum of information that looks somewhat similar to a modern database structure. This structure, which may be called a ramifying catalogue, has a clear internal logic, and is likely to have been created with mnemonic purpose as a response to enormous size of Natural History.

Solinus' ramifying catalogue is indeed similar to the technique of topical memory first described by the author of Rhetorica ad Herennium (3.30-32), and later by Cicero (De Oratore 2.351-358) and Quintilian (Inst. 11.2,17-22) ${ }^{19}$. The use of topical memory is likely to have been widely practiced in rhetorical schools. One should find a continuum full of remarkable 'places', and then 'put' in those places ideas to be remembered. So Cicero says, De Oratore: 2.354:

itaque eis, qui hanc partem ingeni exercerent, locos esse capiendos et ea, quae memoria tenere vellent effingenda animo atque in eis locis conlocanda; sic fore, ut ordinem rerum locorum ordo conservaret, res autem ipsas rerum effigies notaret atque ut locis pro cera, simulacris pro

${ }^{19}$ Visual and topical memory has been discussed in detail by [Elsner, Squire 2016]. 
litteris uteremur (... persons desiring to train this faculty [i. e. memory] must select localities and form mental mages of the facts they wish to remember and store those images in the localities, with the result that the arrangement of the localities will preserve the order of the facts, and images of the facts will designate the facts themselves, and we shall employ the localities and images respectively as a wax writing tablet and the letters written on it — trans. by Sutton and Rackham).

Topical memory relies on visualization, and exploits visual memory to deal with invisible things; visualized mental objects require a visible space ${ }^{20}$, a substratum for places of memory. This large spatial continuum contains a number of smaller "places' disposed in a clear order: Quintilian, Inst. 11.2,18, recommends a big house with many inner rooms, but public buildings, and even pictures, and imaginary objects can also be used (Inst. 11.2,21). Each individual item to be remembered is stored in a place, such as a room, while a large continuum, such as a house, preserves the order of items. What is particularly important is that the recollection of individual items implies an imaginary movement from one place to another following the disposition of a large substratum space. Quintilian gives examples of 'a long journey', and 'a walk through a city' (in itinere longo et urbium ambitu, 11.2).

Topical memory needs a continuum, which itself must be visualized, such as those mentioned by Quintilian. In the case of the Collectanea, an obvious suggestion would be that Solinus used a global map which allowed him to construct an extremely complex, and in general consistent system of routes and geographical areas. In terms of the recommendations made by Quintilian, a map can be considered a kind of picture, maybe an imaginary one.

Though perhaps unexpected, this suggestion is not new: after having summarized Solinus' innovations in managing the large-scale geographical material, Brodersen allowed the possibility that, unlike the 'mapless' Pliny and Pomponius Mela, "Solinus or his readers" might use a map [Brodersen 2011: 87].

Could Solinus use a world map as a wax tablet of memory?

A definite answer is impossible, but two further problems arise from this question.

The technique of topical memory appeals mainly to personal experience. Quintilian, however, speaks about a private house as a preferable locus of memory, and we know, that the Roman house had a standard plan, and this was also true of public buildings and the planning of ordinary Roman towns. Pictures mentioned by Quintilian could be understood as copies of well-known works of famous painters. It seems likely that objects with more or less uniform structure were used in rhetorical schools during the training of topical memory. Presumed world-maps are very ambivalent in this context. They existed in the $3^{\text {rd }}-4^{\text {th }}$ centuries when Solinus was

${ }^{20}$ This point is duly stressed by Cicero, De oratore 2, 357-358: ut res caecas et ab aspectus iudicio remotas conformatio quaedam et imago et figura ita notaret, ut ea, quae cogitando complecti vix possemus, intuendo quasi teneremus. His autem formis atque corporibus, sicut omnibus, quae sub aspectum veniunt, [...] sede opus est ... (things not seen and not lying in the field of visual discernment are earmarked by a sort of outline and image and shape so that we keep hold of as it were by an act of sight things that we can scarcely embrace by an act of thought. But these forms and things, like all the things that come under our view require an abode... - - trans. by Sutton and Rackham). 
active $^{21}$, and they must have been uniform, as far as the disposition of the main geographical regions and areas is concerned. But large maps were rare, so if Solinus could use a map as a substratum image, he could hardly appeal to a wide reading public. Meanwhile, a reader who does not have a sufficiently detailed idea of the coherent geographical universe, would find the Collectanea only a messy conglomeration of names and facts. Understanding Solinus requires an ability to follow his world-wide journey and to construct a mental universal space, perhaps without the help of visible maps, but a reader of the Collectanea must have had a global map in his mind.

The second problem concerns the non-geographical content of geographical host-cells which could not be intuitively clear to anyone but the author. For one may guess that the crocodile should be located in Egypt, but it is difficult to understand why the dolphin is anchored to the Propontis, or Persia serves as a cell for a catalogue of gems, and Africa (where no bears live) is a place where bears are described.

Eventually, it may be suggested that the Collectanea were originally written exclusively for the personal use of the author, and a narrow circle of his friends.

\section{Solinus: Did he knew Rome?}

At the transition point from the historical to anthropological part Solinus listed women who became famous for their extraordinary fertility. Here a certain Eutychis is mentioned, $1.5212,21-23 \mathrm{M}$ :

legimus Cn. Pompeium Eutychidem feminam Asia exibitam, quam constabat tricies enixam, cum viginti eius liberis in theatro suo publicasse (we have read that Gnaeus Pompeius required from Asia a woman called Eutychis, who was known to have given birth to thirty children, and he exposed her together with her twenty children to a public show in his theatre).

When we look at the corresponding text of Natural History, we find immediately that Solinus' version of the story indulges in a gross misrepresentation. For Pliny (7.34) says that, first, the marvelous woman died long ago, and it was at her funeral procession that she was accompanied by 'twenty children', second, it was Eutychis' image that was exposed in the Theatre (more precisely, it stood in the Porticus Pompei $)^{22}$ :

Pompeius Magnus in ornamentis theatri mirabiles fama posuit effigies... inter quas legitur Eutychis a XX liberis rogo inlata Trallibus, enixa XXX partus... (Pompey the Great among the decorations of his theatre placed

21 “... the pre-modern Greco-Roman world generally managed without maps" [Brodersen 2012: 109]. Brodersen has stressed elsewhere that "the first undisputed reference to a map on display dates to AD 297 [Brodersen 2011: 87]. The imaginary map in question is described by Eumenus, De instaurandis scholis, 20, 2 (Panegyr. Lat. 9[4]): [Brodersen 2011: 106; Campbell 2012: 80]. It must be added that Solinus' text does not allow one to distinguish between a painted map and an imaginary map (or a non-iconic representation of the disposition of the World).

${ }^{22}$ The statue of Eutychis was made by Periklymenos [Coarelli 1996: 365]. 
images of celebrated marvels, ... among them we read of Eutychis who at Tralles was carried to her funeral pyre by twenty children and who had given birth 30 times... - trans. by Rackham).

The deviation from Pliny cannot be explained by mere linguistic misunderstanding, and I would suggest, as a possibility, that for this passage Solinus used a corrupt text of Natural History, from which, at a minimum, the word rogo vanished: as a result, he could understand the Plinian phrase inlata Trallibus 'brought to (the pyre) in Tralles' as 'brought into (Rome) from Tralles', and rendered it as Asia exhibitam. Despite this dramatic error, Solinus provided an internally coherent and self-consistent text, which implies that he managed to get an idea of the case of Eytychis from his corrupt source manuscript. Solinus, of course, wrongly understood the situation inferred by Pliny as spectaculum, but it is not surprising that, living in $3^{\text {rd }}-4^{\text {th }}$ cent. $A D$, he did not realize that during the period of the late Republic a woman could not be exposed in a public show in a theatre. It is especially interesting to observe that Solinus' misunderstanding betrays his ignorance of how the Theatre of Pompey was actually built, and how its decoration was arranged, - and ignorance of one of the most important and famous public buildings of Rome ${ }^{23}$ may call into doubt the Roman origin of Solinus suggested by Mommsen ${ }^{24}$. Another point of misunderstanding (which might be a deliberate manipulation) lies in the verb legere. Solinus says legimus, which implies an unnamed written authority ${ }^{25}$, while Pliny surely meant titulus, an inscription which accompanied the statue, when he said effigies... inter quas legitur Eutychis.

\section{Theodericus: The limits of visualization}

The Collectanea gained an enormous and incomprehensible success in the Middle Ages, when its readers were deprived of a key capacity needed to understand Solinus' work: the ability to visualize the global geographical space. From this point of view, the Collectanea were the least suitable text to become a popular encyclopedia, and it seems that it was medieval love for obscurity and artificial complexity that made it one of the most widely read books. The lack of

${ }^{23}$ Discoveries of female statues in relatively good condition, which belonged to the Porticus Pompei [Coarelli 1996: 268-375], prove that the gallery of famous women in the Porticus existed until the end of Ancient Rome, and it might have been known to Solinus. - The Theatre of Pompey has a rich literary history, see, e. g., [Pitcher 2012: 262]. I shall limit myself to one quotation closely related to the theme of Rome as the World. In a letter written by Cassiodorus, and addressed to Symmachus in the first years of the $6^{\text {th }}$ cent. the Ostrogothic king Theoderic stated regarding the grandeur of the Theatre, Cassiodorus, Varia 4.51,4 Mommsen: fecerunt antiqui locum tantis populis parem, ut haberent singulare spectaculum, qui mundi videbantur obtinere dominatum (the ancients built a place equal to such a people, so that those would have an exclusive spectacle, who were seen to obtain the power over the World).

${ }^{24}$ Quo loco libellus scriptus sit, ex ipso non intellegitur, nisi quod cum provinciae omnes memorentur, nulla emineat, inde conicere possis auctorem scripsisse Romae vel certe in Italia [Mommsen 1895: vi] ; for recent discussion see [Brodersen 2011: 64, n. 10].

${ }^{25}$ The same formula is used elsewhere in the Collectanea for anonymous references to Pliny, e. g. 15.7 83,7 M (Albanian dogs), 19.17 95,10 M (deer). 
necessary visual support inspired copyists to add maps to Solinus' manuscripts [Brodersen 2011: 88]. Attempts to visualize the Collectanea led to the reverse influence of the Collectanea upon medieval cartography. Solinus was the most fruitful source of the great Hereford map (ca. 1300) ${ }^{26}$, where we can see images of many mirabilia illustrated by inscriptions which heavily depend on the text of the Collectanea. A large part of the items mentioned by Theodericus is shown on the Hereford map, but Theodericus omitted many important objects and places (such as seas and great rivers) which were necessary constituents of even the most simple and schematic maps, and in no way did Theodericus attempt to give a general image of the world that could be suitable for cartographic representation. On the other hand, he preserved a number of minute items that would require the space of a large and detailed map in which to be visualized, but it is very unlikely that Theodericus could have something like the Hereford map at his disposal.

Single items could be easily represented as visual images, and, like the Hereford map, the poem can be interpreted as a space where the pictures of mirabilia are located $^{27}$. However, Theodericus apparently failed to manage the global continuum of the Collectanea, and the space implied by the poem is loosely structured and cannot be directly associated with any attested type of medieval maps. Theodericus is again 'mapless', and the lack of an internal map is even more manifest in the abridgement by Pseudo-Ovidius ( $\S 1$ above), which consists of short notes arranged as inscriptions to pictures.

\section{Theodericus: The World without a center. Persistence of Roman memory}

Global geography was not the only victim of simplification in Theodericus' poem. The first part of the Collectanea, which deals with Roman history, is totally removed from the De mirabilibus. The text of the poem proves that omission was not accidental or due to textual corruption. In the Prologue, Theodericus says that he intentionally begins with the second, anthropological part of the Collectanea:

\section{4 principium sit homo mihi carminis ordine primo}

(let the human being be for me the beginning, the first unit in the disposition of the poem...)

The approach to the history of other nations is essentially the same. The historical notes and excurses of the geographical part are omitted. This may be demonstrated by looking at the section on India. Theodoricus was very interested in that main land of wonders, and the description of India is one of the largest in the poem (65 lines), but he does not say a single word about the Indian

${ }^{26}$ The problem of the relationship between the Hereford Map and the Collectanea has been revisited in [Kline 2001]. The text of the Hereford map is available with a commentary in a new edition [Westrem 2001].

${ }^{27}$ See [Scully 2017] for the iconography of medieval maps, including the Hereford Map. 
campaign of Alexander the Great, as he does not mention the defeat of Darius (if we turn to Persia) or the numerous cities founded by Alexander. Solinus says about the land of Arbela that "Alexander's victory (scl. at Gaugamela) does not allow to miss this place" (quem locum victoria Alexandri Magni non sinit praeteriri, 46.1 174,5 M). But for Theodericus, the great historical importance of names and facts is likely to have been a reason to exclude them. His idea of mirabilia is generally limited to minor anecdotal matter, consequently, he preserved marginal episodes in which historical figures such as Alexander were involved. Alexander appears in an item about Lacon who was an extraordinarily quick messenger of the Macedonian king $^{28}$, Alexander acts in two stories about animals: he examines Albanian dogs (Th. 313), and organizes a study of longevity of deer (Th. 366). It is difficult to understand why Alexander was erased from the story about a Babylonian dolphin ${ }^{29}$. Bucephalus, of course, is not silenced (Th. 953).

The Bucephalus episode ${ }^{30}$ is worth considering in detail, because it shows the rarest instance of Theodericus' intervention into Solinus' text.
958
959
quem crebro sęve fera per discrimina pugne
960
eripiens, Indi demum post prolia Pori
961
funeris exequias regali munere dignas
962
defunctus meruit sibi quas rex ipse peregit.
963
eius et ob nomen pręclaram condidit urbem
eque Buchefalam parili de nomine dictam

([Bucephalus] often snatched (Alexander) away from dangers of savage battles, at last, he died, and after the fight with Indian Porus, he deserved burial that the King would prepare for himself. Honoring the horse's name, the King founded a glorious city, called from the same name Bucephala).

Solinus added to the Plinian chapter about Bucephalos the statements that the horse had often saved Alexander, and that he had died in India. Theodericus brings in another detail, probably borrowed from Orosius ${ }^{31}$, that Bucephalus was killed in the battle with Porus. The name of Porus is, indeed, superfluous in the story about the horse, unlike the account of the battle, narrated by Orosius, where the name of the Indian king was necessary. The most probable reason of this unexpected addition is that Theodericus wished to demonstrate his scholarly erudition; this might have been seen as ostentatious, because the original source texts of Solinus and Orosius were surely known to Theodericus' readers. I

${ }^{28}$ Th. $139 \rightarrow$ Sol. 1.98 25,11 M $\rightarrow$ Plin. 7.84. Here Theodericus misunderstood his source: the runner's name was Anystis, and he was from Sparta: Lacon (Lacedaemonius, Plin.).

${ }^{29}$ Th. $286 \rightarrow$ Sol. $12.7079,13 \mathrm{M} \rightarrow$ Plin. 9.27.

${ }^{30}$ Th. $952-963 \rightarrow$ Sol. 45.8-9 174,15-175,8 M $\rightarrow$ Plin. 8.154; the name Bucephala was taken by Solinus from Plin. 6.77.

${ }^{31}$ Orosius, Hist. Adv. pag. 3,19,3-4 Zangemeister: ... Alexander cum ipso Poro singulariter congressus, occisoque deiectus equo, concursu satellitum praesentiam mortis evasit ... duas ibi condiddit civitates, Niceam et Bucephalam, quam de nomine equi sui ita vocari praecipt (... Alexander, when he met Porus himself in a single combat and fell from his horse which had been killed, escaped on coming death by the gathering of his bodyguards ... he founded two cities there, Nicaea and Bucephale, which he ordered to be called after the name of his horse - trans. by Deferrari). Porus is not mentioned anywhere by either Pliny or Solinus. 
would suggest that, for the same reason, a large number of personal names were preserved in the poem. But whatever the motives behind Theodericus' choice in each particular case, his general tactics was certainly aimed at reducing information of historical value.

The second part of the Collectanea is paraphrased at length (Th. 39-170), but the section about moral and mental virtues vanished together with the large part of Roman personages, and we may suggest that Theodericus deliberately excluded Roman history from his abridgement. Looking ahead, I would say that the description of Italy, radically reduced by Solinus, almost disappeared from the poem.

Theodericus thus entirely abandoned the idea of Rome as the center of the World.

Theodericus, however, provides a nearly full chorographical account of Palestine (Th. 844-979). The completeness of this section could be due to the poet's religion, but nothing indicates that the Holy Land and Jerusalem were for Theodericus the center of the World, as Jerusalem is shown on the Hereford map ${ }^{32}$.

Theodericus did not add any Christian content to the description of Iudaea. In this, he followed Solinus, who, in the corresponding section, did not list Jewish or Christian monuments. But Solinus mentioned an essentially Roman episode which Theodericus carefully reproduced: Marcus Aemilius Scaurus transferred from Jaffa, and showed in Rome fossils believed to be the bones of the sea-monster (belua) that had threatened Andromede. ${ }^{33}$

838 eius reliquias immania scilicet ossa

839 invexit Romam Marcus cognomine Scaurus

(Its remains, that is to say, the immense bones, were introduced to Rome by Marcus, whose surname was Scaurus).

The Jaffa monster is not the only item related to Roman games and triumphs which survived in De mirabilibus. It is difficult to decide whether Theodericus recognized the Roman spectacula as a special theme, or the persistence of those items could be explained by their frequency in Pliny's Natural History, and then in the Collectanea. In any case, the spectacula mentioned by Theodericus contribute to an image of that Ancient Rome as an extravagant wonderland.

It is not surprising that two continuous notes related to spectacula are about African beasts ${ }^{34}$ :

661 pardalem dicunt Latio sermone camelum

662 viderat hoc animal Latium te consule Cesar

663 viderat et monstra que sunt cefusa vocata

$666 \quad$ Pompei ludis spectacula rhinocherotis

667 vidit Roma potens. cornu prę naribus ingens || surgit...

${ }^{32}$ Jerusalem on the Hereford map has been discussed inter alia by [Deam 2015: 16; Birkholz 2004: 17, 70].

${ }^{33}$ Paleontological aspects of Scaurus' monster have been examined in [Mayor 2000: 138].

${ }^{34}$ Th. 661-667 $\rightarrow$ Sol. 30.19-21 133,20-134,7 M $\rightarrow$ Plin. 8.69, 71. 
([The beast navus $\left.^{35}\right]$ is called in Latin tongue camelopardalis $^{36}$, Latium saw that animal when you, Caesar, were the consul, and another monsters were seen, which are called cefusa ... At Pompey's games, mighty Rome saw a spectacle of rhinoceros: a huge horn rises in front of his nostrils ...)

The words Roma potens (Th. 667) have no correspondence in the Collectanea, but the addition does not necessarily prove that Theodericus was willing to glorify ancient Rome. He is likely to have borrowed the whole hemistich directly from thematically similar Horace, Epist. 1.1,61: arto stipata theatro || spectat Roma potens, - and this quotation, again, merely demonstrates the author's erudition. A metrical pattern could also influence the poet: the expression Roma potens neatly fits the pre-caesural position, and has a good rhyme - ingens. It appears in the same position in classical and early medieval poetry ${ }^{37}$, and Theodericus could treat it as a metrical cliché ${ }^{38}$.

The last episode to be considered here is the show of Eutychis discussed in $\S 5$ above.

$45 \quad$ Eutycides Asię mira pręgnans novitate

46 ter deno partu, Romę - mirabile visu -

$47 \quad$ secum bis denos dedit ad spectacula natos

(The pregnancy of Eutychis ${ }^{39}$ of Asia was something admirable and never known before with her thrice ten births, and — wonderful sight — in Rome she offered herself together with her twice ten sons to a spectacle).

Theodericus renders accurately the content of Solinus' erroneous account. In line with the tendency described above, the poet removed the mention of Pompey, and 'his theatre' was replaced by the wider name of Rome. This change has a remarkable implication: Theodericus still knew that the Theatre of Pompey had been situated in Rome ${ }^{40}$.

\section{Theodericus: The World without an order}

Solinus begins large geographical sections with general overviews, and he is always explicit in descriptions of geographical situations of regions and areas. Theodericus preserves such a landmark only once, when he deals with the transition from the main part of Libya to its wild Oceanic periphery (Th. $309 \rightarrow$ Sol. $31.1136,13 \mathrm{M}$ ):

post gentes Lybicas quas terminat astrifer Athlas

(in the rear of the tribes of Libya whose limits are laid down by starry Atlas)

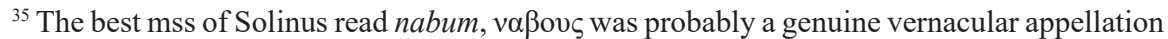
of the giraffe: [Morta 2014].

${ }^{36}$ One should notice a fantastic hyperbaton in Th. 661.

${ }^{37}$ Ovidius, Fasti, 4,106; Statius, Silv., 4.1,28; Alcuin, Carm., 224,2 PL, 101,778 D.

38 The combination of a trochee- and iambus-shaped word in the pre-caesural position was positively admitted, but not particularly favored by Theodericus: according to my calculations, it occurs 54 times (about 5\%), while the prosodically identical clausula, which consists of one choriambic word, occurs 105 times.

${ }^{39}$ Theodericus used a form, Eutycides, incorrectly derived from Eutychidem.

40 This knowledge was by no means trivial in the $11^{\text {th }}$ century. It could be extracted from Lucan, Pharsalia, 7, 9 sqq.
} 
In De mirabilibus, names of large regions are all omitted with few exceptions. Thus, Theodericus does not mention Europe, Asia, Italy, Greece, Scythia, Syria, and so on, though he includes in his epitome places and items from those regions. Eventually, there are only three sections in the poem where the name of a respective area stands in the initial verse which can be read as a rubric: Sicula ora Th. 195, Iudęa Th. 44 India Th. 974. And only these three are rendered with chorographical details more or less fully preserved.

Geographical host entries of the Collectanea are largely lost in Theodericus, who, e. g., retells the story about the ring made of achates, but says nothing about the river Achates and the stone itself (Th. 231). Nonetheless, the episode retained a place in the list of rivers.

Geographical names are sometimes preserved as localizations of lower-level non-geographical items. Theodericus thus does not use the name 'Egypt' in his long description of creatures of that land, but he speaks about the ficus Egiptia (Th. 784) and palma Egiptia (Th. 795). Localizations, however, are removed from a considerable number of items. Long stories about animals lack geographical anchors: dolphins (Th. 257), elephants (Th. 398), lions (Th. 457), horses (Th. 977), and others are described without geographical linkage. The notorious Numidian bears lost their address as well, nonetheless, they retained their position among animals located in Libya. As a result, Theodericus' section about bears (Th. 439456) is placed between elephants and lions.

Any idea of movement through the World disappeared together with indications of large regions.

Not only the large areas, but almost all geographical localizations which formed the knots of Solinus' ramifying catalogue are erased. Theodericus mentions Seleucia and mons Cassius (Th. 880, 881), which are situated in Syria, but all subsequent geographical indications down to India are removed, except for two marginal items. Theodericus tells us about an enigmatic lake Arethusa (it will be dealt with in $\S 10$ ). He then proceeds to the list of stones (Th. 887-910), then an odd creature named animal bonachus appears without any explanation or localization (Th. 911). In order to encounter those items, a reader of the Collectanea would move from the area of Media and the upper Tigris (where the lake is located), through Persia (the list of the stones) to Asia Minor where the bonachus dwells. The bonachus opens a series of marvelous animals of Asia (still not named), and Theodericus states about the chameleon that 'Theutrania sends' 41 that animal (Th. 919). It seems likely that 'Arethusa' and 'Theutrania' are another examples of showy erudition. It is highly unlikely that Theodericus and his milieu knew anything about Teuthrania as a real place, but he probably hinted at his knowledge of Martianus Capella ${ }^{42}$.

In summary, it would be impossible to say that the geographical continuum of the Collectanea was reduced or recomposed by Theodericus, because after being totally destroyed, it was not replaced by any other unifying structure. Large regions are entirely omitted, or mercilessly truncated: no more than 20 lines together are

${ }^{41}$ mittit is a Plinian formula (e. g. Plin. 37.21 about myrrhina quoted above $\S 3$ above) which is favoured by Solinus, e. g. 30.24 134,23 M: Aethiopia mittit lycaonem 'there is the lycaon in Ethiopia'.

${ }^{42}$ Martianus Capella, De nupt. 6.686,6: Supra Troadem in mediterraneo Teuthrania est, quae regio Moesorum fuit, ciuitas vero Teuthrania Caico flumine alluitur. 
devoted to Greece, Thrace and the Aegean Islands. From Solinus' description of Italy, Theodericus took only three items, which occupy about 15 verses:

- there are particular hairs (vilum) in tail of the wolf, they are good as an aphrodisiac (Th. $171 \rightarrow$ Sol. 2.35); 2.38);

- a stone found in the urine of the lynx is a useful medicine (Th. $174 \rightarrow$ Sol.

- corals born in the Ligurian Sea are powerful stones (Th. $179 \rightarrow$ Sol. 2.41).

Theodericus apparently was not interested either in local chorography, or in universal geography, and no idea of the World as a whole can be elicited from his poem.

Theodericus shows a tendency to reduce the matter of the Collectanea to thematic units. Three items extracted from Solinus' description of Italy are likely to form a unit devoted to medical (or magical) remedies. Items concerning rivers and waters were preferred by Theodericus when he abridged the descriptions of Sicily and Greece (Th. 184-247). From Asia Minor he selected animals, including two large stories about the chameleon and horse (Th. 920-939, 947-973). But Theodericus never moved entries from the places they occupied in the geographical grid of the Collectanea ${ }^{43}$. As a result, the thematic arrangement of items is never consistently followed through.

\section{Theodericus: The rubric structure}

The composition of De mirabilibus is strictly linear and unidimensional. Theodericus puts the items of the World catalogue of the Collectanea into separated notes, without transitions and logical connections. This text-building tactic may be illustrated by the transformation of the story of the Olympic victor Milo: it became divided into two notes, one about Milo, and another about the alectorius stone, so that the logical connection between both items (Milo used the stone) was lost:

$98 \quad$ plus quam possit homo potuit quoque robore Milo,
$99 \quad$ qui taurum nudi mactauit uerbere pugni,
$100 \quad$ mactatumque die solidum consumpsit eadem.
$101 \quad$ est allectorius gallorum ventre lapillus:
$102 \quad$ ut faba cristallus specie, pugnantibus aptus.
(and also Milo was strong above the human strength who killed a bull by
a single blow of naked fist, and, during the same day, he ate a killed bull
whole. There is a stone alectorius in the cock's stomach, a crystal which
looks like a bean, this is very good for fighters).

The whole poem displays a typical medieval pattern, with separate isolated chapters that are in large part very short, and that contain no internal information about the global content and structure of the text. This pattern requires regular supratextual pointers (or simply headings, or rubrics) which would make the content and composition explicit. We need rubrics to understand De mirabilibus, as we need a map to understand the Collectanea. In this regard, the cod. Bruxellensis BR 10615729 , shows a rather unusual and inconvenient lay-out: rubrics are not written in the

${ }^{43}$ Few transpositions can still be found, see Appendix II, 10.21; 12.2; 31.1. 
body of the poem, but are collected in a separate block after the Preface ${ }^{44}$, so that they look like a modern table of contents. Most rubrics of the cod. Bruxellensis are related to individual items, and they could be very useful if written within the text, which, in its actual form, is very difficult to navigate through. Some rubrics cover thematic groups, e. g. the section around Milo is rubricated as follows:

- De viribus hominis (covering the gladiator Tritannus, a soldier of Pompey and Milo),

- De allectorio lapide,

- De similitudine hominum (a series of examples).

In two instances, a rubric is a higher-level heading which stands before a series of subordinated individual rubrics:

- Africa in ea serpentes 'Africa, snakes in (Africa)': this is followed by individual rubrics related to snakes: aspis, cerastis, amphisibena, etc. (ad 525 sqq.)

- Mira in India in ea de populis 'wonders in India, in (India) about nations' (ad 975 sqq.): followed by rubrics related in large part to animals, but 'nations' have no special rubrics.

Few individual items are represented by geographical rubrics where geographical names can be combined with thematic information: De Sardoniis herbis et aquis 'about Sardinian herbs and waters' (ad 184), Mons Caucasus piper gignit 'the mount Caucasus generates pepper' (ad 1138), De Gorgada insula in ea de mulieribus sętosis 'about the Isle Gorgada, and in (Gorgada) about furred women' (ad 1167), section on giant snakes from Ganges (Th. 1079) is rubricated as Ganges flumen.

Geographical entries of different higher levels are thus recognized in the list of rubrics, but rubrics offer no additional geographical information which could not be found in the poem. Consequently, most geographical knots are lost in the rubrics, as they are lost in the text. It must be added that the composer of the rubrics $^{45}$ likewise failed to create an overview of the poem based on the thematic principle.

\section{Theodericus: Faults of the source text}

Since Theodericus had but a very vague idea of how the World was arranged in geographical space, he could not recognize scribal errors of his Solinus manuscript, and this affected the coherence of the geographical continuum.

A large section on India (Th. 974-1140) is followed by a short note on abnormal astronomical phenomena observed on the Island of Taprobane (Th. 1141$1146 \rightarrow$ Sol. 53.6 197,1 M). Here the description of Taprobane is interrupted, and the next section of the poem again refers to India, though it contains two items from Solinus' account of Taprobane: the giant long-living people, and the giant sea turtle (Sol. 53.11 198,1-5 M; 53.20 199,5-8 M $\rightarrow$ Plin. 6.91; 9,35). The description of the longlivers begins in the Collectanea with a phrase: ergo inde homines corporum magnitudine omnes homines antecedunt 'so the people from

44 The Vienna excerpt has five rubrics written in the text which are related to the monstrous nations of India (Th. 1000-1021 = W 20-45 Hünemörder), they all are lacking in the cod. Bruxellensis.

${ }^{45}$ The authorship of Theodericus cannot be either proved or rejected. 
there exceed all other peoples in body size'. The word inde became Indi in three Solinus' manuscripts including G (Guelferbutanus 163, Gud. Lat.): ergo indi homines...

The corrupt reading was rendered by Theodericus as:

1147 sunt homines Indi nostro plus corpore magni

(the people of India have bodies bigger than ours)

It is only logical that Theodericus thought that the sea turtle also is related to the people of India; this allowed him to create an uninterrupted narrative about India:

\section{Indis tam patula crescit testudo marina}

(the sea-turtle grows so big for the people of India...)

This passage is remarkable for the descriptive designation of the tortoise shell, which is simply called superficies by Solinus and Pliny ${ }^{46}$ :

\section{Indus ut ipse sibi cratis convexa superni ${ }^{47}$ \\ 1155 Construat hospitium multis habitantibus amplum}

(... that the people of India consruct dweling places for themselves using

the vault of the upper cranial cover: it is large enough for many inhabitants)

Geographical objects were duplicated in two other episodes, so that one name appeared twice in different areas due to scribal errors in the source manuscript. In both cases Theodericus preserved only one of those false homonyms, and in both cases he chose the wrong one.

Theodericus read Arethusa instead of Aretisa (Aretissa Barrington Atlas 89 F2), as in some of the extant Solinus manuscripts, including L (Leidensis Vossianus Q.37) and again G. When he described the lake Arethusa located somewhere in Armenia $(\rightarrow$ Sol. $37.6157,14 \mathrm{M}$ ), he found it necessary to comment that the lake had received its name from Sicily, and this addition proves that the wrong reading was not Theodericus' own error:

\section{4 est lacus a Sicula nomen ducens Arethusa}

(there is a lake which drove its name from Sicilian Arethusa)

However, Theodericus does not mention the famous Sicilian stream at all, though he carefully reports the marvels of Diana and Helbesus, Sicilian rivers which are referred to by Solinus immediately after Arethusa (Th. 209-212 $\rightarrow$ Sol. $15.1651,7-14 \mathrm{M})$.

${ }^{46}$ The most widely used word for tortoise shell is testudo itself, but Pliny had a rich variety of special words: chelium 6.173 ; putamen 9.39 ; cortex 9.40 ; 11.228 ; tegumen 11.188 ; tegimentum 32.34 , — to which two more can be added from other classical authors: testa (an etymology of testudo in Varro, Ling. Lat. 5.79), and concha Calpurnius, Ecl. 6, 68.

${ }^{47}$ The expression used by Theodericus is similar to Pliny's description of the swamp turtle, 32.39: nec convexo curvata calice, - but this similarity does not prove the textual dependence of Theodericus on Pliny, because testudo is a common word for vault (cf. Serv. et Serv. Auct. in Aen. 1,505 , p. $1,157,18$ sqq. Thilo-Hagen). 
Similarly, a false Tygris emerges in Libya (Th. $674 \rightarrow$ Sol. 17.4 90,8 M) because Theodericus read Tigrim instead of Nigrim in his source manuscript, again in accordance with the codd. LG. Theodericus does not mention the true Tigris, a great river which was known as one of the rivers of Paradise, but we certainly know that he carefully read the related entry in the Collectanea, where Solinus explains the etymology of the river Tigris: ita enim nominant Medi sagittam (Sol. $37.5157,14 \mathrm{M})$. From this etymological note Theodericus borrowed the comparison of the tiger (an animal found in Hyrcania) and the arrow, which is absent from the original description of the tiger by Solinus:

341 fertur ut emissa nervo stridente sagitta

(it rushes like an arrow shot by a screeching string)

Finally, Theodericus twice mentions an unheard of nation of Egibanes. This re-

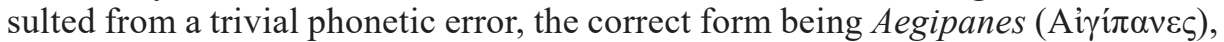
but in this case the wrong reading is not attested in Solinus' manuscripts recorded by Mommsen. It seems unlikely that the accidental error was repeated twice independently, and unification of the wrong spelling was probably due to deliberate efforts by Theodericus. Like the other textual errors examined in this section, the Egibanes prove that De mirabilibus appeared as the result of a careful reading of the Collectanea.

\section{Theodericus: The spaces of the marvelous}

The World of Theodericus is clearly divided in two parts: the Our World of the poet is shown in the Prologue and Epilogue, where Theodericus is shown speaking with his friend Stephanus and working hard on the abridgement of the Collectanea. The Other World existed on the pages of Solinus' manuscript as a mixture of Theodericus' poetic imagination and Solinus' encyclopedic learning.

The poet deleted almost all geographical data from his abridgment, and no geographical reality supported the selection of matter in De mirabilibus. Nonetheless, Theodericus strictly observes a global border of crucial importance: the space he totally ignores in his narrative closely corresponds to the limits of the Christian World as it was established ca. 1100, where Byzantine Greece and Italy (in large part Byzantine too) formed a transitory zone. Arab Sicily was conquered by the Normans by 1072 , and it belongs to the zone covered by De mirabilibus as a non-Christian country. Palestine and the entire central zone of the medieval Mappa Mundi is equally included in that Other World ${ }^{48}$. The Our World is carefully silenced by Theodericus in the body of the poem, but apart from Christian Europe there is another silenced zone in De mirabilibus which is situated in the Far East: this is the eastern periphery of the World where the medieval Paradise was usually located ${ }^{49}$. Again, Theodericus carefully avoided the theme of the Terrestrial Paradise,

${ }^{48}$ The density of monsters and marvels increased to the periphery, and monsters are generally located in the periphery of medieval maps [Mittman 2006: 45-59]

${ }^{49}$ See inter alia the evidence collected in [Mittman 2006: 48]. 
and he said nothing about the rivers of Paradise, which were one of the key elements of medieval cosmology (see the river Tigris above).

It must be added that no special geographical zone of marvels was established by Pliny or Solinus. Classical thought viewed marvelous events and things as immanent to Nature ${ }^{50}$, and Pliny collected mirabilia throughout the World as precious embellishments of the Roman Empire.

The Other World described by Theodericus was inhabited by strange, often dangerous, and suspect creatures, but he knew that, though segregated in space, monsters were a part of the World created by God. This idea is explicitly expressed in the Prologue, where the poet says that God is a mirabile who creates all mirabilia:

38 que volo mirari mirabilis ipse creasti

(Thou, admirable, created what I want to admire)

Monsters and other marvelous things were seen as manifestations of God's will and Providence ${ }^{51}$, and one might expect that Theodericus would pay attention to this aspect of his theme, but he again says nothing explicitely. I would suggest that the apparent silence provides a key for understanding the significance of the poem, which was probably intended to be read as a multilevel allegory $^{52}$.

I would refer here to a large description of elephants (Th. 398-438), which has two allegorical dimensions clearly highlighted by the poet.

The first is the moral allegory, by no means is it hidden. Elephants are good animals of the medieval bestiary, and their moral virtues are described at length by Theodericus, who pays special attention to the 'marriage of elephants'. The sexual behavior of animals and exotic peoples is often reported by Theodericus, but the marriage of elephants has a particular significance: it is widely attested as a theological, or so called anagogic allegory which should induce a spiritual meaning. A pair of male and female elephants could represent Adam and Eve [Hassig 1995: 131-133]. The section ends with the scene of a fight between elephants and dragons, where the elephant is identified with Christ. The allegorical meaning of this episode is self-evident, but it is additionally emphasized by the numerous Christological allusions listed in Appendix I.

${ }^{50}$ The illuminating study of the history of the notion of miracle can be found in [Grant 1952].

${ }^{51}$ See [Friedman 1981; Verner 2005] for the problem of adapting mirabilia to the theological frame. In a personal conversation, prof. Isabel Velázquez has pointed me to the fact that the problem was known to Isidore (11.3.4).

${ }^{52}$ Cf. the poem De lapidibus by Marbode of Rennes, which was supplemented by an allegorical commentary soon after it was written [Riddle 1977: 125-129]. 


\section{Appendix I. Elephant as Christ}

426. Hi sęvos hostes patiuntur sępe dracones

427. Qui circumventos astu spirisque ligatos*

428. Cruribus et pedibus compellunt figere gressus

429. Ne valeant truncis se vel coniungere saxis*

430. Et perimant hostes collisos mole terentes*

431. His nam deceptis astu sollertior hostis

432. Absorbet largum captati sanguinis haustum

433. Donec ad extremum terra se proicit ipsum

-Ad sextam, Analecta Hymnica 51, 16, s. 8: Advenus omnes impetus || Quos saevus hostis incutit

- Gregorius Turonensis, Historia Francorum, 6, 5 p. 270, 13, Krusch-Levison: Deus hominem creavit innoxium, sed astu serpentis circumventus, praevaricator praecepti factus est: et ideo a sede paradisi eiectus, mundanis laboribus deputatus est; qui per mortem Unigeniti Dei Christi Deo reconciliatus est Patri.

- Hieronymus, Dialogus contra Luciferianos, PL 23, 170A: ... haererem certe trunco crucis, nec prius amitterem, quam misericordiam impetrarem

- Cantus in dedicatione ecclesiae, Analecta Hymnica 51, 103, s. 3: Haec domus rite tibi dedicata || Noscitur, in qua populus sacatum || corpus assumit, bibit et beati || Sanguinis haustum

- Act. 13, 47: ut sis in salutem usque ad extremum terrae (Isa. 49, 6)

434. Emoriens elephas exhaustus sanguine venas

435. Vincens victorem quem casu proterit hostem

- Alcuinus, Epistola CCII. De comparatione numerorum (PL 100 477B: Tribus modis Adam tentatus eft ... Tribus his modis (iterum) Christus tentatus eft, et vicit victorem Adae.

- Cyprianus, Iesus Nave, 395: desuper incurrens securum proterit hostem || omnia caede madent tellusque infecta cruore est.

436. Quorum conspersa permixto sanguine terra

437. Fiet cinnabaris vulgo cruor ipse draconis

438. Dictus picturę satis utilis et medicinę

* Solinus 25, 10-15 p. 112,18 113,7 M $\rightarrow$ Plinius 8, 32-34 denique insidiae hoc astu praeparantur ... primumque pedes nodis ligant, ut laqueatis cruribus inpediant gradiendi facultatem: nam elephanti, nisi praeventi hac spirarum mora, vel arboribus se vel saxis applicant, ut pondere nitibundo attritos necent angues ... ob id a draconibus avidissime torrente captantur aestu ... 


\section{Appendix II. Correlation between the geographical parts of the Collectanea and De mirabilibus}

Braces indicates items where Theodericus does not provide a geographical location. $\dagger$ marks the textual errors discussed in $\S 10$.

\begin{tabular}{|c|c|c|}
\hline $\begin{array}{l}\text { Solinus } \\
\S \S\end{array}$ & $\begin{array}{c}\text { Solinus: Regions of the Geographical } \\
\text { Part }\end{array}$ & Theodericus: Terrae \\
\hline & Italy $_{1}$ : from Liguria to Sicily & \\
\hline 2.19 & Italy, general description & - \\
\hline 2.24 & primus Eropae sinus & \\
\hline 2.24 & secundus Europae sinus & \\
\hline \multirow[t]{2}{*}{2.26} & Memorabilia of Italy & \\
\hline & & [Medicines] \\
\hline 2.35 & Italia lupos habet & \{cauda lupi: 170 \\
\hline 2.40 & Cicadae apud Reginos multae & - \\
\hline 2.45 & Insula Diomedis & - \\
\hline 2.41 & Ligusticum mare & equora Ligustrica: 179 \\
\hline 2.51 & Italy ${ }_{2}$ : Italicus excursus & \\
\hline 2.51 & Dalmatia, Illyricum & \\
\hline 3.1 & the Islands near the western shore of Italy & - \\
\hline $3.2 / 3$ & Corsica & - \\
\hline 4.1 & Sardinia & $\begin{array}{l}\text { Sardonia herba: } 184 \\
\text { [Waters] }\end{array}$ \\
\hline 5.1 & Sicily & Sicula ora: 195 \\
\hline \multirow[t]{2}{*}{5.9} & Aethna & Ęthna: 202 \\
\hline & - & Ęthnensis campus: $207 *$ \\
\hline 5.16 & Arethusa & - \\
\hline 5.16 & Diana & fons Dianę: 209 \\
\hline 5.17 & Helbesus & Helbesus: 211 \\
\hline 5.17 & Himeraea & Hemereus: 213 \\
\hline 5.18 & sal Agrigentinus & Agrigentinus sal: 218 \\
\hline 5.18 & Aethna: sal purpureus & Ęthna: sal purpureus: 220 \\
\hline 5.20 & Halesina regio & fons Alisinę: 221 \\
\hline 5.21 & Gelonium stagnum & Gelonium: 225 \\
\hline 5.24 & Ager Agrigentinus & Ager Agrigentinus: 228 \\
\hline
\end{tabular}

[Balcan region: Dalmatia, Raetia, Noricum, Pannonia, Moesia. The region, which was coverd by the province of Illyricum, is described by Pliny (3.141-150) as a side route from Histria to Moesia. It is entirely omitted by Solinus. A short list of the areas of Illyricum is inserted in the section on Gallia:] 
$7.1 \quad$ Tertius Europae sinus Greece: from

$\begin{array}{ll} & \text { Epirus to Thessaly } \\ 7.2 & \text { Epirus: a miraculous spring }\end{array}$

7.3/4 Achelous

fons Epiri: 237

7.5 Greece: from Patrae to Magnesia in Thessaly

Achelous: 241 from Thessaly to the Propontis

9.1 Macedonia

$10.1 \quad$ Thrace

10.17 Propontis

10.21 Propontis: Abydos and Sestos

11.1 Aegean Islands and Crete

[moved to the section related to 12.2]

11.3 Crete

\subsection{Euboea: Carystos}

11.17 the Cyclades

$11.24 \quad$ Euboea $_{2}$

11.26 the Islands

11.33 Lemnos, Myrina, Athos

12.1 quartus Europae sinus

12.2 Hellespontus: Xerxes' bridge

[no unifying theme]

Caristos: 248

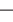

$-$

Lemnos, Myrina,

Athos: 250-253

Hellespontus:

Xerxes' bridge: 254

Abydos and Sestos:

256 (transferred from 10.21)

\section{from Hellespontus to Scythia}

\section{[The dolphin]}

$\begin{array}{ll}\text { 13.1 } & \text { Hister } \\ 13.2 & \text { Pontus }_{1} \\ 15.1 & \text { Borysthenes apud Neuros } \\ & \text { Nations of Northern Scythia } \\ \text { 15.2 } & \text { Neuri } \\ 15.3 & \text { Geloni } \\ 15.3 & \text { Agathyrsi } \\ 15.4 & \text { Anthropophagi } \\ 15.5 & \text { Chalybes. Dahae } \\ 15.5 & \text { Albani } \\ 15.13 & \text { Essedones } \\ 15.14 & \text { Scythi }\end{array}$

\section{From Pontus $_{1}$ to Hyrcania}

15.17 Dioscoridas, urbs Colchorum

15.18 The Caspian region: general description, Araxes, Euphrates are mentioned

15.20 Arimaspi

Euphrates - Araxes - Caspius: 333

15.20 Riphaeum iugum

Riphei: 335

Neuri: 298

[Geloni: 302]

[Agathyrsi: 303$]^{* *}$

Andropophagi 305

Albani: 308

Essedones: 326

15.22 Asiatica Scythia (grypes)

15.23 Arimaspi ${ }_{2}$ (grypes)

16.1 Hyperborei

17.1 Arimphaei

17.3 Cimerii 
17.3 Amazones

17.3 a channel from Caspium mare to Scythicus Oceanus

From the Far North back to the South (magnis spatiis intercedentibus)

$17.4 \quad$ Oxus

17.4 $\quad$ Hyrcania $\left._{1}\right)$ Hyrcani (tigres)

Hyrcania ${ }_{1}$ (pantheres)

18.1 Pontus

19.4 mare Caspium

19.6 from Pontus to insula Abalcia: nations of Abalcia region:

19.7 Hippopodes

19.8 Phanesii

19.9 animals of Scythia

Germania: from mons Saevo to Rhine

20.1 Germania: a general description

20.3 Saltus Hercynius

20.7 Germania from Gangavia insula to Rhine

21.1 Gallia from Rhine to the Pyrenees

$22.1 \quad$ Britannia

21.2 The eastern neibours of Gallia: Raetia, Noricum, Pannonia, Moesia are listed

22.2 Hibernia

22.9 Thyle

$22.10 \quad$ Britannia $_{2}$

$23.1 \quad$ Hispania

23.5 Lusitania

23.13 Gaditanum fretum, an overview of the Oceanus

24.1 Excursus from Hispania to Libya, the Pillars of Hercules a general description of the African continent

24.6 Sala oppidum

Libya: the Mediterranean zone from the Atlas to Cyrene

24.7 Atlas mons: Aegipanes

25.1 Tingitana: elephants

25.16 Caesarea in Numidia

$26.1 \quad$ Numidia

$26.3 \quad$ Numidici ursi

27.1 Africa and Carthage

27.13 animals of Africa: lions, etc.

27.27 snakes of Africa

$27.38 \quad$ Syrtes

27.41 Psylli

27.44 Cyrene

27.53 Cyrene: the basilisk, remains of a basilisk preserved in Pergamon
[Marvelous animals]

Hircania (tigres):

336

Hircani

(pantera): 342

Hippopodi: 352

Phanesii: 353

animals of Hircinia:

373

一
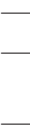

-

一

$-$

-

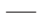

Athlas: 393

$\dagger$ Egibanes: 395

\{bears: 439

\{lions: 457

Africa, serpentes: 525

remains of a

basilisk preserved in

Pergamon: 564

Syrtes, Cyrene 580

Psylli: 589

[moved to to the section related to 27.27] 
Libya, the inner zone: from Cyrene to

'Ethiopia', and westwards to the Atlas

27.55 The region of the Garamantes: an overview

28.1 gens Amantum

29.1 Garamantum oppidum Debris

29.8 Gauloe insula

$30.1 \quad$ Aethiopes vs gentes Atlanticae

30.2 Garamantici Aethiopes

$30.4 \quad$ Nomades, etc: a catalogue of peoples

30.8 Cynomolgi

$30.8 \quad$ Artabatitae

30.9 Meroe

$30.10 \quad$ Macrobii

30.12 Monstruosae gentes

30.14 Ethiopia: a detailed description, including: dracontia lapis

30.22 Nigris fluvius: catoblepas

30.29 Aethiopici lupi

$31.1 \quad$ Libya: the Oceanic periphery, moving to the East from the Atlas to Egypt

30.2 a catalogue of people

$31.1 \quad$ Atlantes

31.3 Trogodytae

$31.4 \quad$ Augilae

$31.4 \quad$ Gamphasantes

31.5 Blemyae

$31.6 \quad$ Satyri

31.6 Aegipanes

31.6 Himantropodes

31.6 Pharusi

32.1 Egypt and Nile: a detailed description, including

32.16 a note about 'expirations' of Nile

32.34 ficus Aegyptia

32.36 palma Aegyptia

$32.41 \quad$ Alexandria

33.1 Arabia: a digression from Pelusium to Arabia and back to Pelusium

$33.11 \quad$ Phoenix

33.18 precious stones of Arabia, including

33.21 androdamas
[Marvelous

nations]

Debris castrum: 597 gens

Garamantum:

Gaulensis insula:

597

609

customs of

Garamantes:

625

Cynomolgi: 621

Artabatiti: 622

Macrobii: 625

monstriferae

gentes: 632

\section{[Animals]}

$\dagger$ Tygris: 674

Ęthiopum lupus: 698

[Marvelous

nations]

[moved to

$31.3^{* * *}$ ]

Trogoditę: 710

Athlantes: 716

Blemiae: 720

Satyrae: 722

Egibanes: 724

Himandropodes: 727

[Egypt and Arabia]

Non spirat nebulas

Nilus: 729

Egiptia ficus: 784

Egiptia palma: 793

mare Rubrum: 796

Phoenix: Araps $=$

Arabia: 811

\{andradamas: 831 
From Pelusium to Palestine and Syria, up to the mons Cassius

34.1 an overview of Palestine and Syria

$31.2 \quad$ Iope

35.1 Iudaea

35.1 Iordanis

35.1 Paneas

35.2 Asphaltites lacus

35.3 lacus Sara

35.3 lacus Tiberiadis

35.4 Hierosolyma

35.4 Hierichus

35.4 Calliroe

35.7

35.9 Esseni

Syria

36.1 a list of cities of Syria, including

36.2 Seleucia

36.2 mons Cassius

Armenia: the upper Euphrates and Tigris

37.1 a detailed description of the region, including

37.6 Aretisa lacus

the upper Mesopotamia and Persis

37.7 a catalogue of Stones: Chaldei, Parthi Persis

From Mesopotamia to the West: Asia

$38.1 \quad$ Cilicia

40,1 Asia (in narrow sense)

40.7 Phrygia

40.10 Phrygia: bonachus

40.12 Ionia

40.20 Teuthrania

40.21 Asia: Chamaeleon

40.25 Pythones come: ciconia

41.1 Galatia

$42.1 \quad$ Bithynia

43.1 Ora Pontica

44.1 Paphlagonia

45.1 Cappadocia

45.5 Cappadocia: the horse

From Cappadocia to Assyria, and to Far East

46.1 Assyria

46.4 Media

47.1 Portae Caspiae: Lapiri, Narici, Hyrcani
[Judea and Syria]

castrum Ioppe: 832

Iudęę regio: 844

Iordanis: 845

Paneas: 846

Asfaltites: 848

Tiberias: 853

Iherosolim: 856

Iherichus: 858

Calliroe: 860

Gomorrum,

Sodomum: 876

Seleucia: 880

mons Cassius: 881

lacus Arethusa: 884

\section{[Stones]}

\{sagada petra: 887 , and other stones

\section{[Animals]}

\{animal bonachus:

911

Theutrania: 919

Theutrania:

chamęleon: 919

\{ciconia: 940

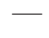

$-$

$-$

\{the horse: 947 
48,1 from Caspii to the East

49.1 Oxus

49.2 Bactri

$50.1 \quad$ longa deserta

50.1 Anthropophagi

50.2 Tabin

50.2 Seres

51.1 Attacenus sinus

\section{India and Taprobane}

52.1 Medi montes, India

India: 974/975

[Nations]

A detailed description of India, including a catalogue of peoples

52.30 fons Gangis: people feeding on smells

nations of India: 977

Gangis fons: 1011, people

feeding on smells

52.33 India: snakes

52.34 animals of India, including

Serpentes Indi: 1032

53.36 Indici tauri

52.37 mantichora

52.42 Indica maria: Balenae

52.46 India: ficus

52.49 Tylos Indiae insula

52.50 mons Caucasus

[Animals]

Indi tauri: 1052

India: manticora:

1059/1060

Indica aeqora: balenae:

1089

Indica ficus: 1111

Tylos insula: 1125

montes Caucasii: 1128

Taprobane: 1141

homines †Indi: 1147

53.11 people of Taprobane

53.20 the tortoise of Taprobane

testudo marina: 1153

Indus

$54.1 \quad$ Western India

54.2 Indus flumen

54.4 From Indus to Alexandria

54.5 Periplus from Alexandria to India: an overview

54.11 Carmania

54.12 Rubrum Mare

54.13 Persis

55.1 Parthia

56.1 Chaldaea gens: Babylonia

56.4 Oceanic shores of Libya nations of Ethiopian deserts:

[Nations]

56.9 Trogodytae,

Trogoditę: 1162

56.9 Ichthyophagi

Hicthiophagi: 1164

56.10 Gorgades insulae Gorgada insula: 1167

56.16 Iunonia insula

56.17 Capraria, Nivaria, Canaria insulae

* An addition from an unknown source.

** The three nations are confused, and described as Neuri, this may be a fault of the source ms. *** Perhaps a scribal error of the cod. Bruxellensis. 


\section{References}

Birkholz, D. (2004). The king's two maps: Cartography and culture in Thirteenth-Century England. New York: Routledge.

Brodersen, K. (2011). Mapping Pliny's world: The achievement of Solinus. Bulletin of the Institute of Classical Studies, 54(1), 63-88.

Brodersen, K. (2012). Cartography. In D. Dueck. Geography in Classical Antiquity, 99-110. Cambridge: Cambridge Univ. Press.

Brodersen, K. (Ed.) (2014). Solinus: New studies. Heidelberg: Verlag Antike.

Campbell, B. (2012). Rivers and the power of Ancient Rome. Chapel Hill: Univ. of North Carolina Press.

Coarelli, F. (1996). Il complesso pompeiano di Campo Marzio e la sua decorazione scultorea. In F. Coarelli. Revixit ars: arte e ideologia a Roma: dai modelli ellenistici alla tradizione repubblicana, 360-381. Roma: Quasar. (In Italian).

Deam, L. (2015). A world transformed: Exploring the spirituality of medieval maps. Eugene, Oregon: Wipf and Stock Publishers.

Dover P. (2013). Reading Pliny's 'ape' in the Renaissance: The Polyhistor of Caius Julius Solinus in the first century of print. In J. König, G. Woolf (Eds.). Encyclopaedism from Antiquity to the Renaissance, 414-443. Cambridge: Cambridge Univ. Press.

Elsner, J., Squire, M. J. (2016). Sight and memory: The visual art of Roman mnemonics. In M. J. Squire, J. Elsner (Eds.). Sight and the ancient senses, 180-204. London: Routledge.

Flint, V. I. J. (1982). Honorius Augustodunensis. Imago mundi. Archives d'histoire doctrinale et littéraire du Moyen Âge, 49, 7-153.

Friedman, J. B. (1981). The monstrous races in medieval art and thought. Cambridge, Mass.: Harvard Univ. Press.

Geus, K. (2016). Paradoxography and geography in antiquity: Some thoughts about the Paradoxographus Vaticanus. In Fr. J. González Ponce, Fr. J. Gómez Espelosín, A. L. Chávez Reino (Eds.). La letra y la carta: Descripción verbal y representación gráfica en los diseños terrestres grecolatinos; Estudios en honor de Pietro Janni, 243-257). Madrid: Universidad de Alcalá, Servicio de Publicaciones: Sevilla: Editorial Universidad de Sevilla.

Grant, R. (1952). Miracle and natural law in Graeco-Roman and early Christian thought. Amsterdam: North Holland.

Hassig, D. (1995). Medieval bestiaries: Text, image, ideology. Cambridge: Cambridge Univ. Press.

Haupt, M. (1876). Index lectionum aestivarum 1863. In M. Haupt. Opuscula (Vol. 2), 218-252. Lipsaie: Impensis Salomonis Hirzelii. (In Latin).

Healy, J. F. (1999). Pliny the Elder on science and technology. New York: Oxford Univ. Press.

Hünemörder, Ch. (1976). Das Lehrgedicht "De monstris Indie" (12. Jh.). Ein Beitrag zur Wirkungsgeschichte des Solinus und Honorius Augustodunensis. Rheinisches Museum für Philologie, 119(3), 267-284. (In German).

Jakobi, R. (2002). Indien in der Solin-Paraphrase des Theodericus. Mittellateinisches Jahrbuch: internationale Zeitschrift für Mediävistik, 37(2), 247-256. (In German).

James, M. R. (1913). Ovidius de Mirabilibus mundi. In E. C. Quiggin (Ed.). Essays and studies presented to William Ridgeway on his sixtieth birthday August 1913, 286-298. Cambridge: Cambridge Univ. Press.

Janni, P. (1984). La mappa e il periplo: cartografia antica e spazio odologico. Roma: Bretschneider. (In Italian). 
Kaffarnik, A. (2011). Querela magistri Treverensis. Neuedition, Übersetzung und Kommentar. Mit einer Beschreibung der Handschrift Bruxelles, BR 10615-729. Bern: Peter Lang. (In German).

Kline, R. N. (2001). Maps of medieval thought: The Hereford paradigm. Rochester, NY: Boydell Press.

McDermott, W. C. (1938). The ape in antiquity. Baltimore: The Johns Hopkins Press.

Manitius, M. (1914). Zur poetischen Literatur aus Bruxell. 10615-729. Neues Archiv der Gesellschaft für ältere deutsche Geschichtskunde, 39, 155-175. (In German).

Mayor, A. (2000). The first fossil hunters: Paleontology in Greek and Roman times. Princeton: Princeton Univ. Press.

Mittman, A. S. (2006). Maps and monsters in medieval England. New York: Routledge.

Mommsen, Th. (Ed.) (1895). C. Iulii Solini Collectanea rerum memorabilium. Iterum recensuit Th. Mommsen. Berolini: Apud Weidmannos. (In Latin).

Morta, K. (2014). Did Agatharchides mention an African name of giraffe? Živa antika = Antiquité vivante, 64, 73-92.

Murphy, T. (2004). Pliny the Elder's Natural History: The Empire in the encyclopedia. Oxford: Oxford Univ. Press.

Naas, V. (2011). Imperialism, mirabilia and knowledge: Some paradoxes in the Naturalis Historia. In R. K. Gibson, R. Morello (Eds.). Pliny the Elder: Themes and contexts, 57-70. Leiden: Brill.

Pavlock, B. (2014). Paradox and the journey in the dedicatory Preface of Solinus' Collectanea. In K. Brodersen. (Ed.). Solinus: New Studies, 24-31. Heidelberg: Verlag-Antike.

Pitcher, L. V. (2012). Cassius Dio. In I. J. F. de Jong (Ed.). Space in Ancient Greek literature: Studies in Ancient Greek Narrative (Vol. 3), 257-268. Leiden: Brill.

Ramosino, L. C. (2005). Mamilio Sura o Emilio Sura? Alcune considerazioni sulla teoria della successione degli imperi nella 'Naturalis Historia' di Plinio il Vecchio. Latomus, 64(4), 945-958. (In Italian).

Reiffenberg, Fr. de. (1841). Notice d'un manuscrit de la bibliothèque royale. Bulletin de l'Académie royale de Bruxelless sciences, des lettres et des beaux-arts de Belgique, 8(2), 247-267. (In French).

Riddle, J. M. (Ed.) (1977). Marbode of Rennes'De Lapidibus: Considered as a medical treatise with text, commentary, and $C$. W. King's translation, together with text and translation of Marbode's Minor works on stones. Wiesbaden: Steiner.

Rutledge, S. H. (2012). Ancient Rome as a museum: Power, identity, and the culture of collecting. Oxford: Oxford Univ. Press.

Schmidt, P. L. (1995). Solins Polyhistor in Wissenschaftsgeschichte und Geschichte. Philologus, 139(1), 23-35. (In German).

Scully, D. (2017). Medieval maps and diagrams. In C. Hourihane (Ed.). Routledge companion to medieval iconography, 399-411. London: Routledge.

Seel, O. (1982). Pompeius Trogus und das Problem der Universalgeschichte. In Aufstieg und Niedergang der römischen Welt (Vol. 2.30.2), 1363-1423. Berlin: W. de Gruyter. (In German).

Talbert, R. J. A. (2008). Greek and Roman mapping: Twenty-first century perspectives. In R. J. A. Talbert, R. W. Unger (Eds.). Cartography in antiquity and the Middle Ages: Fresh perspectives, new methods, 9-27. Leiden: Brill.

Verner, L. (2005). The epistemology of the monstrous in the Middle Ages. New York: Routledge.

Verweij, M. (2015). Florus and his 'Vergilius Orator an Poeta': The Brussels Manuscript revisited. Wiener Studien, 128, 83-105. 
Westrem, S. D. (2001). The Hereford map: A transcription and translation of the legends with commentary. Turnhout, Belgium: The Folio Society.

Woodard, R. D. (2006). Indo-European sacred space: Vedic and Roman cult. Urbana: Univ. of Illinois Press.

Ziolkowski, J. M., Putnam, M. C. J. (Eds.). The Virgilian tradition: The first fifteen hundred years. New Haven: Yale Univ. Press.

$* * *$

\section{Информация об авторе}

\author{
Александр Евгеньевич Кузнецов \\ доктор филологических наук \\ дочент, филологический факультет, \\ кафедра классической филологии, \\ Московский государственный \\ университет им. М. В. Ломоносова \\ Россия, ГСП-1, 119991, Москва, \\ Ленинские Горы, 1-й корпус \\ гуманитарных факультетов \\ Тел.: + 7 (495) 939-32-77 \\ сотрудник, Эйнштейн-Центр Chronoi, \\ Свободныи университет Берлина (Freie \\ Universität Berlin) \\ Otto-von-Simon-Str., 7 \\ 14195, Berlin, Germany \\ Тел.: +49 (30) 838-52768 \\ recubanssub@googlemail.com
}

\section{Information about the author}

\author{
Alexander E. Kuznetsov \\ Dr. Sci. (Philology) \\ Assistant Professor, Philological Faculty, \\ Department of Classical Philology, \\ Lomonosov Moscow State University \\ Russia, 119991, Moscow, Leninskie Gory, \\ GSP-1, $1^{\text {st }}$ Corpus of the Humanities \\ Tel.: +7 (495) 939-32-77 \\ Fellow, Einstein Centre Chronoi, Free \\ University of Berlin \\ Otto-von-Simon-Str., 7 \\ 14195, Berlin, Germany \\ Тел.: +49 (30) 838-52768 \\ recubanssub@googlemail.com
}

